\title{
Sopi Maluku Diantara Cultural Capital Dan Market Sphere
}

\author{
Grantino Milando Pattiruhu ${ }^{1 *}$, Wilson M. A. Therik ${ }^{1}$
}

*Universitas Kristen Satya Wacana, Indonesia

\section{A R T I C L E I N F O}

\section{Article history:}

Accepted 10 Desember

2020

Available online 31

Desember 2020

Kata Kunci:

Sopi Maluku; Modal

Kebudayaan; Market

Sphere

\section{Keywords:}

Sopi Maluku; Cultural

Capital; Market Sphere
Received 19 Agustus 2020

\begin{abstract}
A B S T R A K
Keberadaan minuman tradisional jenis Sopi yang terdapat di daerah Maluku sampai dengan sekarang ini masih menjadi perdebatan dan pertentangan di kalangan pemerintahan. Sopi yang sejak dulu menjadi Cultural Capital orang Maluku kini mendapat penolakan dari pemerintah ketika ada dan masuk dalam Market Sphere sebagai usaha ekonomi rumah tangga. Penelitian ini bertujuan untuk memperoleh gambaran yang utuh tentang Sopi di antara Cultural Capital dan Market Sphere dalam kehidupan masyarakat Kota Ambon serta memperoleh gambaran yang jelas tentang Sopi di antara produsen, konsumen, dan kebijakan pemerintah Maluku. Jenis penelitian ini adalah penelitian kualitatif dengan pendekatan fenomenologi. Teknik pengumpulan data menggunakan teknik dari Miles dan Huberman yaitu wawancara mendalam, observasi, dan kajian dokumentasi dan menggunakan analisis dengan tahapan reduksi data, penyajian data (display
\end{abstract} data) dan penarikan kesimpulan setelah semua data terkumpul dan dilakukan verifikasi. Hasil penelitian menunjukan bahwa harapan terbesar selalu diberikan dari masyarakat kepada pihak pemerintah untuk meregulasikan Sopi agar mendapatkan pengawalan sehingga terhindarkan dari kontroversi yang nantinya merugikan salah satu pihak. Sopi secara Cultural Capital sudah legal keberadaannya, namun pada Market Sphere Sopi masih belum mampu diregulasikan oleh pemerintah daerah. Hal ini dibuktikan dengan adanya penyitaan dan razia Sopi yang selalu dilakukan di Kota Ambon oleh pemerintah dan aparat keamanan. Penelitian ini diharapkan dapat memberikan kontribusi positif bagi pihak pemerintah daerah provinsi Maluku perihal keberadaan Sopi dan dapat mengeluarkan regulasi terhadap minuman lokal tradisional jenis Sopi dan bagi masyarakat produsen Sopi diharapkan dapat mengatur dan mengembangkan dengan baik minuman lokal ini sampai ke tangan konsumen.

\begin{abstract}
A B S T R A C T
It has been currently known that he existence of traditional Sopi drinks found in Maluku up to currently it is still a matter of debate and controversy among the Maluku Provincial Government. Sopi, which has always been the Cultural Capital of the Maluku people now received resistance from the government when it existed and entered the Market Sphere as a business household economy. This study aims to obtain a complete picture of Sopi between Cultural Capital and Market Sphere in Ambon City community life as well get a clear picture of Sopi among producers, consumers, and policies Maluku government. This type of research is a qualitative research approach phenomenology. Data collection techniques using techniques from Miles and Huberman, namely in-depth interviews, observation, and review of documentation and using analysis with stages of data reduction, data presentation (data display) and drawing conclusions after all the data collected and verified. The research result shows that the biggest hope is always given from the community to the government to regulate Sopi in order to get escort so as to avoid controversy that later harms one of the parties. Sopi is in Cultural Capital legal existence, but in the Market Sphere Sopi is still there has not been able to be regulated by the local government. This was evidenced by the confiscation and the raids on Sopi which were always carried out in Ambon City by the government and security forces. This research is expected to make a positive contribution to the local government Maluku province regarding the existence of Sopi and can issue regulations on beverages local traditional types of Sopi and for the community Sopi producers are expected to organize and developing this local drink well into the hands of consumers.
\end{abstract}




\section{Pendahuluan}

Negara Sopi Maluku adalah sebutan untuk minuman keras beralkohol yang dikenal oleh kalangan komunitas lokal orang Maluku. Sebagai minuman lokal, Sopi diolah dan diproduksi secara tradisional menggunakan pengetahuan yang diwariskan secara turun temurun sejak dari zaman dahulu hingga sekarang ini. Penggunaan dan pemanfaatan Sopi dalam kehidupan seharihari masyarakat Maluku terus terjadi hingga sekarang ini. Secara etimologi, Kata Sopi berasal dari bahasa Belanda zoopje yang berarti alkohol cair atau minuman beralkohol lokal, Sopi mengandung 50\% kadar alkohol (Pelamonia, 2016). Sopi Maluku tergolong dalam minuman keras lokal masyarakat yang mendapatkan banyak pertentangan dan perdebatan terkait dengan peredarannya di tengah masyarakat. Di Maluku, Sopi dijadikan sebagai alasan pemicu tindak kriminal sehingga Sopi harus dimusnahkan dan disita oleh pihak keamanan yang berwajib (Polisi dan Tentara Nasional Indonesia). Pemerintah Provinsi Maluku (dalam hal ini Gubernur Maluku) mengimbau masyarakat untuk berhenti berdebat dan mencari legitimasi Sopi, karena perdebatan ini akan menimbulkan kontroversi di masyarakat. (Kompas.com, 2019). Tidak cukup sampai kepada pelarangan, aksi razia dan penyitaan Sopi juga dilakukan sebagai bentuk tindakan tegas untuk memberantas Sopi di Maluku. Tepat pada hari Jumat 7, Februari 2020, minuman keras jenis Sopi ditumpahkan oleh aparat kepolisian setempat di pelabuhan Yos Sudarso, Ambon sebanyak 2.400 Liter dalam rangka pemusnahan minuman keras yang tersebar di Kota Ambon (Kabartimur, 2020).

Selain di Maluku, di Indonesia pada umumnya, razia minuman keras lokal rutin terjadi di beberapa daerah pelosok tanah air. Polres Jayawijaya melakukan razia di sejumlah tempat pembuatan minuman keras lokal. Razia tersebut dilakukan di seputaran Kota Wamena Papua. Polisi rutin menggelar razia karena dapat memicu seseorang untuk melakukan tindakan kriminal usai meneguk minuman keras. Razia ini rutin dilakukan Polres Jayawijaya guna memberantas peredaran penjualan miras di Jayawijaya, karena banyak orang mabuk sehingga meresahkan masyarakat serta memicu terjadinya tindak kriminal di Jayawijaya(Nur Habibie, 2020). Daerah Palu Sulawesi Tengah, Kepolisian juga menyita ratusan liter minuman keras tradisional jenis cap tikus dari oknum pedagang yang berjualan di salah satu kios di wilayah Kota Palu (Malaha, 2020). Menjelang libur Natal dan tahun baru 2020, ribuan liter minuman keras yang diamankan hasil Operasi Pekat Agung II tahun 2019 dimusnahkan Polda Bali untuk pengamanan Natal dan tahun baru difokuskan pada penanganan kejahatan jalanan (Kadafi, 2019). Di Kota Semarang, Polda Semarang meningkatkan operasi terhadap massa, minuman beralkohol, dan pengemasan menjelang Lebaran. Alhasil, berhasil mengamankan puluhan orang dan ratusan liter minuman campur. "Patroli digelar di bulan Ramadan yang dalam kondisi pandemi Covid-19 ini. Sasarannya merazia minuman keras (M Agus Haryanto, 2020). Disisi lain, dengan adanya penertiban dan razia minuman keras lokal pada beberapa daerah di Indonesia, pulau Nusa Tenggara Timur (NTT) telah meluncurkan produk minuman keras lokal dengan merk "Sopia" ke pasaran nasional untuk membantu Memperkuat kapasitas minuman lokal, sehingga lebih meningkatkan perekonomian masyarakat (Petrus, 2019). Selain Sopia dari NTT yang sudah legal peredarannya, Cap Tikus yang merupakan minuman lokal khas Kota Manado juga telah resmi dilegalkan dan diluncurkan ke pasaran sebagai minuman khas daerah yang bebas diperjual-belikan (Handoyo, 2019).

Penelitian yang dilakukan Lendo (2014) tentang kelompok usaha para petani pohon seho yang mengupayakan dan memberdayaan pohon seho untuk memperoleh keuntungan ekonomis. Penelitian ini terjadi di Desa Tokin baru, Motoling Timur, Kabupaten Minahasa Selatan, Sulawesi Utara. Usaha kelompok tani pohon seho telah berhasil meningkatkan pendapatan masyarakat melalui usaha pengolahan pohon seho menjadi minuman lokal tradisional yang di kenal dengan sebutan cap tikus. Dengan mengolah cap tikus, petani di Desa tokin baru dapat memberdayakan anggota masyarakat sehingga meningkatkan kesejahteraan hidup setiap anggota masyarakat yang pengangguran. Kegiatan mengolah pohon seho menjadi nilai usaha ekonomis telah menjadi mata rantai usaha dan tikenui hingga saat ini. Setiap anggota yang terlibat dalam kelompok usaha tersebut mendapatkan keuntungan perbulannya sebesar Rp. 4.500.000 hal ini berdampak positif bagi pengembangan perekonomian warga pedesaan. Di Nusa Tenggara Timur kepulawan Ende terdapat tradisi minuman lokal dengan sebutan Moke. Dalam penelitiannya, Fransiska, Saka and 
Nainggolan (2019) menyimpulkan bahwa Moke mempunyai bagian dalam ritual adat kematian, perkawinan dan ritual adat lainnya yang dilakukan di NTT. Moke dipandang berdampak baik bagi tumbuhnya solidaritas antar masyarakat yang didalamnya nilai kekeluargaan sangat tinggi, namun dampak negatif juga ada dalam hal ini seperti terjadinya perkelahian yang diindikasi akibat mengkonsumsi Moke secara berlebihan.

Di Maluku, penelitian tentang sopi telah dilakukan oleh (Sarioa, 2011) di Wotay Teon Nilan Serua Maluku Tengah yang menjelaskan bahwa sopi juga digunakan dalam proses rekonsiliasi masyarakat. Bagi mereka sopi adalah hal yang sakral dalam kehidupan manusia. Satu botol sopi yang dikonsumsi oleh masayarakat didalam perkumpulan tertentu dapat menyelesaikan sebuah permasalahan. Hal rekonsiliasi dalam permasalahan ini merupakan tanda pengesahan terhadap kesepakatan bersama. (Setiawan, Syafar and Riskiyani, 2013), dalam penelitiannya memberikan kontribusi terhadap produsen sopi di Maluku tenggara. Keaktifan masyarakat dalam mengolah pohon lontar untuk menghasilkan tuwak/sopi, ini memberikan dampak positif bagi perekonomian keluarga. (Saleky, 2016) dalam penelitiannya di desa Romkisar, terdapat adat yang dapat mengikat hubungan antara suami dan istri agar taat kepada nilai-nilai hidup. Adat ini disebut Tiris Sopi, hal ini dipercaya dapat mendatangkan kebahagiaan dalam hidup berumah tangga dan keberhasilan dalam hal keuangan.

Penelitian ini fokus pada Sopi dan keberadaannya diruang publik Maluku yang mencakup Cultural Capital dan Market Sphere di mana penulis belum menemukan literatur yang secara khusus mendalami Sopi Maluku dalam Cultural Capital dan Market Sphere. Adapun permasalahan yang terjadi dikalangan pemerintah Provinsi Maluku dengan masyarakat lokal terkait dengan pelegalan dan tuntutan regulasi minuman Sopi. Dengan demikian perlu untuk dilakukan penelitian lebih lanjut mengenai Sopi yang awalnya merupakan minuman adat khas orang Maluku sekaligus sebagai bagian dari mata pencaharian utama masyarakat lokal menjadi indikasi pemicu terjadinya tindak kriminal, sehingga penelitian ini diharapkan dapat memberikan kontribusi positif bagi pihak pemerintah daerah provinsi Maluku perihal keberadaan Sopi dan dapat mengeluarkan regulasi terhadap minuman lokal tradisional jenis Sopi dan bagi masyarakat produsen Sopi diharapkan dapat mengatur dan mengembangkan dengan baik minuman lokal ini sampai ke tangan konsumen.

\section{Metode}

Penelitian ini merupakan penelitian kualitatif dengan metode fenomenologi Penelitian ini bertujuan untuk menunjukkan fenomena atau gejala sosial Sopi di Maluku antara Cultural Capital dan Market Sphere. Untuk pengumpulan data primer digunakan teknik wawancara mendalam (indepth interview) dan observasi non partisipasi, sedangkan data sekunder dikumpulkan dengan cara melakukan penelusuran dokumentasi tentang Sopi Maluku berdasarkan pemberitaan di media cetak dan media online dan dokumen resmi pemerintah (Creswell, 2015). Untuk analisis data digunakan analisis data menggunakan analisis model (Miles and Huberman, 1994) dengan tahapan reduksi data, penyajian data (display data) dan penarikan kesimpulan setelah semua data terkumpul dan dilakukan verifikasi.

\section{Hasil dan Pembahasan \\ Sopi dalam Cultural Capital}

Minuman tradisional Sopi masih digunakan dalam acara atau ritual adat yang selalu dilakukan di berbagai Negeri adat di Kota Ambon sebagai simbol kebudayaan orang Maluku. Konsumsi Sopi paling banyak terjadi ketika ada acara-acara pesta pernikahan (orang maso rumah), pesta keluarga, acara-acara gerejawi, ritual adat Negeri seperti pelantikan raja (Negeri Latuhalat dan Negeri Hatalai), panas pela seperti yang sering terjadi pada Negeri Latuhalat dengan Negeri Alang. Sopi digunakan dalam ritual dan acara-acara tertentu tetapi masih dalam pengawasan pemerintah Negeri dan pihak keamanan setempat untuk tetap menjaga ketenteraman masyarakat. 
Tetapi untuk mengkonsumsi Sopi pada hari-hari biasa jarang terjadi bahkan kurang". Sopi juga dipergunakan dalam ritual adat panas pela Negeri Hatalai dan Negeri Amahusu sebagai simbol dalam ritual adat. Penggunaan Sopi dalam acara tersebut selalu dikontrol dan diawasi untuk aturan-aturan penggunaannya. Penggunaan Sopi dalam ritual adat juga terjadi pada Desa Layeni Kecamatan Teon Nila Serua (TNS). Sopi digunakan dalam ritual adat pelantikan raja. Dalam acara pelantikan raja tersebut, Sopi disediakan dalam botol kemudian dilakukan penyumpahan adat oleh ketua adat dan dibagikan Sopi tersebut kepada setiap orang yang hadir pada saat itu dengan takaran Sopi di gelas sloki (Wattimena, 2013).

Dalam ritual adat pihak keamanan juga turut terlibat dan berpartisipasi untuk menjaga keamanan demi keberlangsungan acara adat yang diselenggarakan. Dalam kesempatan itu pula fungsi kontrol dari pihak keamanan dalam hal ini anggota kepolisian maupun anggota Tentara Nasional Indonesia (TNI) juga mengawasi peredaran dan konsumsi Sopi yang berlebihan. Apabila terjadi kegaduhan dan kericuhan dalam ritual adat yang disebabkan oleh anggota masyarakat yang mengkonsusmi Sopi dengan berlebihan, orang tersebut akan ditangkap dan diamankan dan diberikan sanksi sesuai aturan dan hukum yang berlaku. Pengakuan juga datang dari BA Polsek Leitimur Selatan terkait dengan mengkonsumsi Sopi, menurutnya, melarang Sopi untuk dikonsumsi dalam ritual adat berarti orang yang melarang tersebut telah melanggar hukum adat. Hanya saja fungsi kontrol dari pihak keamanan tetap ada demi terciptanya keamanan dalam masyarakat. yang masih berhubungan erat dengan minuman beralkohol. Di Bali contohnya, dalam pelaksanaan ritual Bhuta Yadnya. Ritual ini merupakan ritual suci yang dipercaya dapat menghilangkan atau mengusir roh jahat yang selalu menperhampat hidup orang bali seperti mendapatkan penyakit hingga kematian. Dalam ritual tersebut arak bali selalu disertakan sebagai suatu minuman adat. (LEMBAGA BANTUAN HUKUM MASYARAKAT, 2015).

Tidak terbatas pada keempat Negeri tersebut. Yakni Negeri Latuhalat, Alang, Hatalai, Amahusu, pada umumnya Negeri-negeri adat di Maluku selalu menggunakan Sopi sebagai minuman tradisional turun temurun yang dilestarikan dan diyakini memiliki nilai sakral.Sedikit berbeda dengan Negeri-Negeri adat yang ada di Maluku, penggunaan Sopi pada ritual adat mengalami sedikit perbedaan dalam mekanismenya. Ketika Negeri-negeri adat di Maluku yang diharuskan menghadirkan Sopi dalam ritual adat mereka, Negeri Batumerah dan Negeri Passo yang memiliki hubungan pela berbeda dalam menggunakan Sopi. Dalam setiap ritual adat yang dilakukan, Sopi tidak selalu diwajibkan dikonsumsi dalam ritual tersebut tetapi Sopi tetap hadir. Hal ini dikarenakan adanya latar belakang masyarakat adat Negeri Batumerah yang mayoritas beragama Islam. Dalam paham masyarakat Batumerah, Sopi haram. Dikarenakan Sopi termasuk minuman keras dan memabukan, ajaran agama dan dogma mereka meharamkan minuman lokal jenis Sopi tersebut.

"Jikalau kami masyarakat Batumerah ada dalam ritual adat dengan Negeri Passo, Sopi tidak menjadi minuman wajib dikonsumsi. Kami berbeda dengan Negeri adat lain. Kami selalu membangun kesepakatan dengan Negeri pela kami yaitu Negeri Passo agar Sopi tersebut dikonsumsi atau dinikmati semaunya atau dengan sukarela saja. "Siapa yang mau minum Sopi ya minum, kalau tidak minum juga tidak menjadi masalah diantara kami terkhususnya kami yang muslim. Dan ini sudah menjadi kesepakatan bersama antara kami Negeri Batumerah dan Negeri Passo".

Sopi adalah minuman adat, minuman tradisional orang Maluku. Sopi sudah ada dari zaman tete nene moyang hingga sekarang ini. Sopi sudah berakar dan mendarah daging dalam ingatan maupun ritual-ritual kebudayaan orang di Maluku. Sopi telah menghidupkan persaudaraan serta pertemanan yang tak kenal batas suku rasa dan agama.

Beta ni hidop dar Sopi. Beta pung orang tatua dolo-dolo tifar Sopi par katong ade kaka bisa skolah. Makanya coba lia beta pung sekeliling rumah ni banya deng pohong mayang karena beta piara ini pohong. Ini merupakan berkat yang Tuhan kasi dar dolo sampe sakarang ini par katong. Kaong musti jaga akang. Beta pung 


\begin{abstract}
hidop rang basudara tetap terjaga. Katong selalu kumpul orang basudara dan di situ katong minong Sopi lalu katong carita kahidopang pung bae-bae. (Saya hidup dari hasil pengolahan Sopi. Saya punya orang tua dari dulu mengolah Sopi untuk kami adik dan kakak bisa sekolah. Oleh karena itu coba lihat sekeliling rumah saya banyak sekali pohon enau karena dilestarikan dan juga merupakan berkat yang diberikan oleh Tuhan dari dulu hingga sekarang ini yang harus di jaga. Kehidupan saya dengan keluarga-keluarga saya tetap terjaga. Kami selalu berkumpul satu dengan yang lain sesame keluarga-keluarga dan di situ kami minum Sopi lalu bercerita tentang kehidupan yang baik). (Y.L, 14 Januari 2020)
\end{abstract}

Penggalan wawancara tersebut memberikan sebuah fakta bahwa Sopi telah hadir dalam kehidupan orang Ambon sudah cukup lama dan menjadi warisan turun temurun yang harus dijaga hingga sekarang ini. Sopi menghadirkan nilai persaudaraan yang tinggi yang hadir untuk mempersatukan. Sopi telah lama hadir dalam kehidupan adat budaya di Maluku. Menghilangkan Sopi berarti menghilangkan adat dan tidak usah bikin acara adat, maka di situ akan terjadi kematian anak-anak adat yang melanggar adat tersebut". Penggunaan Sopi dalam ritual adat di Maluku semuanya sama. Sopi tetap hadir dalam ritul, karena penggunaan Sopi sudah terjadi turun temurun dan merupakan warisan budaya di Maluku. Oleh sebab itu penggunaan Sopi merupakan simbol yang diberikan dari zaman leluhur hingga sekarang ini sebagai alat pemersatu.

Aspek budaya yang dihormati dan dinilai sakral yang disandangkan pada Sopi di Maluku juga terjadi di daerah lain di Indonesia. Desa Merita salah satunya. Terletak di Kabupaten Karangasem pulau Bali, arak merupakan produksi minuman traditional secara home industry. Masyarakat meyakini bahwa proses pengolahan dan produksi Arak mengikuti tradisi pembuatan minuman tradisional Arak yang biasa digunakan dalam kegiatan persembahyangan dan upacara adat di Bali. Selain itu, masyarakat telah mewarisi teknologi pembuatan dan pengolahan minuman Arak, dan setiap keluarga di Desa Merita masih mempraktikkannya. Keyakinan yang kuat tersebut pula merupakan hal yang paling unik karena pembuatan arak yang memiliki pilosophi yang kuat tersebut berkaitan dengan kepercayaan masyarakat setempat terhadap dewa yang beristana di Pura Desa. Minuman traditional arak Bali merupakan jenis minuman yang mengandung alkohol dan biasanya digunakan dalam kegiatan upacara adat dan keagamaan sebagai sajian "tabuhan" pada aktivitas budaya dan keagamaan di Bali (Indrayathi, 2004)

Pemerintah Kota Ambon harus memperhatikan aset budaya yang ada di Maluku. Jangan seenaknya saja main tumpah-tumpah Sopi. Harus butuh kajian yang mendalam terlebih dahulu baru ambil tindakan. Pemerintah tidak memikirkan rakyat kecil. Pemerintah harus memperjuangkan minuman Sopi ini. Kami jadi ragu dengan gubernur kami sekarang ini apakah beliau merupakan anak adat Maluku atau tidak". Maluku lahir dari hasil adat istiadat. Sopi sangat menolong bagi masyrakat kecil untuk penghidupan keseharian tiap keluarga masyarakat di Maluku terkhususnya para produsen Sopi. Selain produsen Sopi yang diuntungkan, Sopi juga merupakan minuman tradisional yang mempunyai khasiat yang manjur untuk dipakai sebagai obat tradisional untuk menyembuhkan sakit penyakit. Jika dibandingkan, keuntungan dari Sopi dengan hasil kebun lain, Sopi sangatlah menguntungkan daripada berkebun. Alasanya pertama mengenai jangka waktu panen untuk hasil kebun dan jangka waktu pengolahan untuk Sopi. Sopi setiap hari ada pemsaukan berupa keuntungan uang dari hasil penjualan Sopi. Sedangkan hasil kebun harus menunggu beberapa bulan baru bisa dipanen dan menghasilkan uang.

Mengingat Provinsi Maluku yang mempunyai potensi wisata yang banyak mulai dari laut, pantai, gunung, sampai kepada kuliner yang berupa makanan dan minuman, Sopi juga dapat dijadikan sebagai wisata kuliner. Sopi dapat menjadi wisata kuliner di Maluku apabila Sopi berhenti untuk diperdebatkan dan mulai untuk mengregulasikannya. Wisata kuliner minuman keras tradisional yang dapat kita temui di dunia ada pada Negara Jepang yang terkenal dengan Minuman sakenya. Sake merupakan minuman beralkohol yang berasal dari Jepang, sake merupakan minuman yang terbuat dari beras hasil fermentasi. Pada saat yang sama, pemerintah Jepang sendiri telah mengeluarkan definisi sake sebagai minuman beralkohol yang 
terbuat dari beras, nasi koji dan air, yang kemudian difermentasi dan disaring. Definisi ini terutama mengacu pada jenis sake tradisional yang tidak umum di Jepang. Di Jepang, sake bisa dijual gratis di tempat umum. Sake bisa ditemukan di banyak tempat rekreasi (Alex, 2019).

Perdebatan dan penolakan serta pelarangan beredarnya Minuman tradisional jenis Sopi pada ruang publik telah menimbulkan polemik antara pihak pemeritahan provinsi Maluku dan masyarakat setempat. Permasalahan ini terjadi diakibatkan oleh wacana yang dikeluarkan oleh Gubernur Maluku bahwa Sopi di Maluku tidak akan dilegalisasikan karena Sopi adalah pemicu terjadinya kriminal. Selain itu penyitaan hingga pemusnahan Sopi ini terus terjadi di Kota Ambon yang dilakukan oleh pihak keamanan dalam hal ini polisi dan tentara. Tindakan yang dilakukan oleh pihak pemerintah dan pihak keamanan di Maluku ini lalu menimbulkan perlawanan dari masyarakat setempat. Perlawanan tersebut dilakukan dikarenakan: 1) Pendapat dan pemahaman masyarakat terkait Sopi yang adalah bagian dari tradisi dan kebudayaan orang Maluku, yang telah ada dan hadir dalam ritual-ritual adat di Maluku sejak dahulu kala. 2) Sopi telah menghidupi sebagian masyarakat Maluku dalam ranah ekonomi mikro (usaha rumah tangga). 3) Kebijakan pemerintah yang sewenang-wenang tanpa memikirkan rakyat kecil. Kebijakan serta polemik tentang Sopi sampai dengan saat ini belum mendapatkan titik terang serta jalan keluar terhadap keberlanjutan dan regulasinya. Terkait dengan permasalahan Sopi di Maluku, satu langkah maju yang bisa menjadi acuan yang baik bagi pemerintah Maluku adalah, Arak Bali kini teregulasi. Gubernur Bali I Wayan Koster pada 5 Februari 2020 lalu mengumumkan legalnya minuman ikonik yang terbuat dari pohon lontar tersebut. Hal ini tercatat dalam Peraturan Gubernur No. 1 Tahun 2020 tentang Tata Kelola Minuman Fermentasi dan/atau Destilasi Khas Bali. "Saya mengharap, dengan telah diatur dalam Pergub, maka minuman fermentasi khas Bali ini menjadi kekuatan ekonomi baru kita berbasis kerakyatan dan kearifan lokal Bali," ujar Koster saat dikonfirmasi media (Hastanto, 2020).

\subsection{Sopi dalam Market Sphere}

Sopi di Negeri Latuhalat banyak peredarannya pada ruang publik. Acara adat dan juga hari-hari besar gerejawi, Sopi tetap hadir dalam perayaan tersebut tetapi itu hanya yang terpantau pada konsumen yang menkonsumsi Sopi. Memproduksi Sopi sekarang ini pada Negeri Latuhalat sudah mulai berkurang, hanya ada satu, dua orang saja. Sopi yang dikonsumsi di Latuhalat adalah Sopi yang didatangkan dari luar Negeri Latuhalat dan juga di bawa masuk bukan hanya oleh orang Latuhalat sendiri melainkan ada juga orang-orang yang dari luar Negeri Latuhalat yang mengimpor Sopi tersebut secara liar karena kemungkinan besar mereka juga adalah pedagang Sopi. Mereka yang mendatangkan Sopi tersebut ada yang dari Dusun Eri, Negeri Amahusu, dari daerah Ambon gunung bahkan juga dari luar pulau Ambon yaitu dari pulau Seram bahakan pulau Tenggara Maluku. Razia minuman keras juga terjadi di Negeri Latuhalat, karena Sopi sudah menjadi pusat perhatian dari aparat keamanan dengan alasan penertiban dan menghindari terjadinya tindak kriminal di masyarakat. Raja Negeri Latuhalat mengatakan bahwa: "pada Tahun kemarin, pihak gereja di Latuhalat (Pendeta dan Majelis Jemaat) bekerja sama dengan pihak kepolisian Nusaniwe, dalam hal ini polsek Nusaniwe untuk merazia miras lokal jenis Sopi tersebut. Apa bila kedapatan Sopi pada masyarakat baik itu konsumen atau produsen Sopi, tanpa menunggu waktu lama langsung buang atau di tumpahkan ke laut".

Alasan pihak keamanan menyita Sopi yang menjadi alasan timbulnya tindak kriminal, adalah salah satu alasan yang tidak dikaji dengan tuntas. Menurut (Rini, 2012), Dalam hasil penelitiannya menjelaskan tentang empat faktor perilaku krimial antara lain; 1. faktor ekonomi, 2. Faktor sosial, 3. faktor kondisi fisiologis, 4. Foktor psikologis. Berdasarkan keempat faktor dalam penelitian perilaku tindak kriminal tidak saja terjadi akibat mengkonsumsi minuman keras misalanya saja seseorang susah dalam membiayai hidup bisa saja melakukan tindak kriminal. Kemudian tindak kriminal juga diakibatkan oleh salah pergaulan, atau fisiologis seseorang terganggu dan tidak dapat mengendalikan diri dan ego yang tinggi mungkin saja dapat menjadi pemicu tindak kriminal. Aksi mengenai kriminalitas juga dalam faktor psikologis diakibatkan oleh traumatik masalalu yang pernah dialami oleh seseorang. Dengan demikian terdapat banyak faktor yang dapat mempengaruhi kriminalitas, bukan hanya sopi. 
Om Paci (sapaan pada seorang narasumber) sebagai produsen Sopi, ia menjadi penjual Sopi pihak kedua. Ia juga menjual Sopi yang bukan olahannya di rumahnya. Sopi tersebut adalah hasil kerja sama ia dengan teman sesama penjual Sopi dengan harga Rp 170.000/jerigen ukuran lima liter dan jika dijual dalam kemasan per botol bir Rp 35.000. Sopi hasil olahan sendiri dijual dengan harga Rp 275.000/jerigen ukuran lima liter alasannya karena Sopi yang asalnya dari penada dalam hal ini Sopi dari pihak pertama diserahkan ke pihak kedua ini asalnya dari pulau Seram.

Selain produksi Sopi (tifar mayang), adapun pekerjaan lain yang dilakukan seperti membakar batu bata. Di Negeri Latuhalat memang banyak sekali pekerjaan yang ditekuni oleh masyarakat di sana. Pekerjaan wirausaha tersebut sangatlah beragam, ada yang nelayan, produsen Sopi, pengusaha batu bata, jibu-jibu (penjual ikan). Bapak (Benony Latupputi) ia terlibat dalam dua usaha kerja rumah tangga seperti membakar batu bata dan memproduksi Sopi. Menurut Benony Latuputti, keuntungan dari membakar batu bata lebih besar dari pada tifar. Penghasilan dari mencetak batu bata sekitar Rp. 20.000.00. dalam jangka waktu satu tahun. Berbeda dengan penghasilan dari tifar mayang hanya Rp. 6.000.000 per tahun. Tetapi memproduksi Sopi juga sangatlah membantu ekonomi keluarga. Tiap hari dari memproduksi Sopi ada pemasukan dan pendapatan. Sopi diolah dan dimasak dalam jangka waktu dua hari bahkan tiga hari lalu Sopi diolah atau disuling untuk siap di pasarkan. Sopi dijual per satu jerigen dengan harga Rp. 250.000 dengan harga per botol dalam kemasan botol bir Rp. 35.000 dengan tingginya penikmat atau konsumen Sopi di Negeri Latuhalat. Konsumen Sopi datang dari usia remaja hingga orang tua. Menurutnya, Sopi satu jerigen bertahan hanya satu hari, besoknya lagi Sopi sudah habis terjual dan laris di pasaran.

Tabel 1

Tabel Perbandingan Harga Batu Bata dan Sopi

\begin{tabular}{|c|c|c|c|c|c|}
\hline No & Batu Bata & Harga & No & Sopi & Harga \\
\hline 1 & $\begin{array}{l}\text { Satu Buah Batu } \\
\text { Merah }\end{array}$ & Rp. 1000 & 1 & 1 Botol Bir & Rp. 35. 000 \\
\hline 2 & Penghasilan Satu Tahun & Rp. 20.000 .000 & $\begin{array}{l}2 \\
3\end{array}$ & $\begin{array}{l}1 \text { Jerigen ( } 5 \text { Liter) } \\
\text { Penghasilan Satu Tahun }\end{array}$ & $\begin{array}{l}\text { Rp. } 250.000 \\
\text { Rp. } 6.000 .000\end{array}$ \\
\hline
\end{tabular}

Sumber: Hasil wawancara dengan Bapak Benony Latuputy

Razia Sopi juga sering dilakukan di Dusun Erie kecamatan Nusaniwe. Razia ini sering dilakukan tiap Tahunnya. Dalam satu Tahun razia yang dilakukan dari pihak kepolisian polsek Nusaniwe dapat terjadi tiga sampai dengan lima kali. "Sopi bisa dilarang dan di razia, tetapi kasihan kami yang mebutuhkan Sopi ini untuk keberlangsungan kehidupan keluarga kami". Ujar bapak S.D. S.D merupakan seorang kewang Kota Ambon dan juga sebagai tuagama di gereja, ia berpendapat bahwa "Kadang-kadang peraturan dari pemerintah tidak menjamin kesejahteraan keberlangsungan kehidupan rakyat kecil, kalau Sopi di razia, kami tidak bisa mengolah bir, wiskhy dan drum untuk mendatangkan pemasukan dalam ekonomi keluarga kami. Bir dan minuman yang sudah berlebel lainnya sudah mendapatkan tempat yang aman di etalase-etalase prtokoan di seluruh Kota Ambon ini. Tetapi Sopi? Apakah itu bisa di atur ataukah tidak dalam aturan sehingga kami juga diperhatikan selaku rakyat kecil" Ujar bapak S.D. Harapan bapak S.D selaku produsen Sopi, kiranya ada perhatian dari pemerintah untuk melihat hal ini. Jangan anggap sepeleh, razia sering dilakukan produsen Sopi dirugikan. Sopi dijual dan dipasarkan di Dusun Erie dengan harga per botol bir Rp. 50.000. harga Sopi tersebut baru saja naik harganya mulai Desember 2019 hingga Januari 2020. Alasan utama harga Sopi naik tersebut dikarenakan meninggkatnya permintaan dari konsumen Sopi dibandingkan dengan air sageru yang dihasilkan pada pohon mayang yang menurun atau berkurang. Produsen Sopi di daerah Dusun Erie tidak terlalu banyak, tetapi ketika dibandingkan dengan Negeri Latuhalat, Dusun Erie masih melebihi jumlah dari Latuhalat. Meskipun tidak terlalu banyak pula perodusen Sopi di Erie, tetapi pohon mayang penghasil air sageru sangat banyak tumbuh di hutan Erie. 
Tepat dengan pelarangan yang berujung razia. Masyarakat merasa akses terhadap minuman beralkohol menjadi semakin sempit dan sangat terbatas sehingga banyak masyarakat yang telah berhenti untuk mencari dan mengkonsumsi minuman ini. Dalam ilmu ekonomi, ketika stok sedikit dan permintaan produk tinggi maka akan berdampak pada harga produk naik. (Yamani, 2018). Banyak negara dalam beberapa studi mengemukakan bahwa peradaran alkohol telah dilarang peredarannya namun banyak pasar gelap makin banyak menjual minuman beralkohol ini. Banyak yang eksperimen dibuat untuk mendapatkan minuman beralkohol, namun eksperimen itu tidak baik bagi kesehatan manusia dan dapat mengancam hidup seseorang jika dikonsumsi. Amerika serikat adalah salah satu negara pertama yang menerapkan larangan perihal minuman beralkohol. Pemerintah pada tahun 1920 melarang semua penjualan dan produksi alkohol. Akibatnya organisasi kriminal memperoleh kekayaan tak terbatas dengan menjual minuman yang dipalsukan secara ilegal. Kemudian tahun 1961 di India pemerintah melarang masyarakat di Ghujarat untuk mengkonsumsi minuman beralkohol. Namun kebijakan yang dibuat oleh pemerintah India gagal dalam memberantas perdagangan minuman beralkohol. Terlepas dari upaya untuk penggebrekan dan menjatuhkan hukuman berat kepada pedagang alkohol, polisi tidak dapat menghentikan peredaran alkohol. Menurut statistik yang dirilis pemerintah pada 2017, sebanyak $10 \%$ penduduk Iran minum alkohol secara teratur. Di Indonesia, ratusan orang meninggal setiap tahun karena minum. Menurut penelitian yang dilakukan oleh Pusat Riset Kebijakan Indonesia (CIPS), sejak maraknya pelarangan alkohol pada tahun 2010, konsumsi alkohol telah melonjak hingga 75\%. Sementara itu, lebih dari 58\% orang yang mengonsumsi oplosan alkohol mengaku memilih minuman berbahaya ini karena murah dan mudah ditemukan. Peran negara dan pemerintah adalah menjadi dewasa terhadap kecenderungan warga negara dan mengorganisir warga negara untuk menjadi dewasa terhadap diri mereka sendiri dan orang-orang di sekitar mereka. kasus lain terjadi di Indonesia, ratusan orang meninggal setiap tahun karena minum minuman beralkohol. Menurut penelitian yang dilakukan oleh Pusat Riset Kebijakan Indonesia (CIPS), sejak maraknya pelarangan alkohol pada tahun 2010, konsumsi alkohol telah melonjak hingga 75\%. Sementara itu, lebih dari 58\% orang yang mengonsumsi oplosan alkohol mengaku memilih minuman berbahaya ini karena murah dan mudah ditemukan. Peran negara dan pemerintah adalah menjadi dewasa terhadap kecenderungan warga negara dan mengorganisir warga negaranya untuk menjadi dewasa terhadap diri mereka sendiri dan orang-orang di sekitar mereka (Yamani, 2018).

Meskipun razia Sopi sering dilakukan, tetapi bapak S.D juga sering lolos dari razia tersebut, dikarenakan adanya hubungan baik dengan pihak kepolisian. Bapak S.D memiliki sanak saudara dan keluarga banyak yang memiliki profesi sebagai polisi dan tentara (TNI). Tetapi adanya sikap hati-hati yang selalu di terapkan oleh bapak S.D ketika ada orang yang tidak dikenal datang dan membeli Sopi dirumahnya. Ketakutan seperti itu karena kadang-kadang, intel yang menyamar sebagai pembeli Sopi untuk mencaritahu keberadaan Sopi. Dalam proses penjualan Sopi yang terjadi di Erie, mereka memiliki suatu tradisi ketika ada orang yang datang dan membeli Sopi. Tradisi tersebut adalah tradisi perjanjian yang dilakukan oleh penjual Sopi kepada pembeli Sopi. Janji tersebut hanyalah singkat dan padat yang berbunyi: "Kalo minom Sopi jangan sampe mabo lalu jang bikin kaco", karena ini se bali dar beta katong dua musti saling membantu" artinya bahwa jikalau mengkonsumsi Sopi nantinya jangan sampai mabuk agar supaya ada saling menguntungkan dari produsen maupun konsumen. Untuk daerah Erie konsumsi Sopi sangatlah banyak. Sopi yang diproduksi sebanyak apapun dari produsen Sopi, mampu bertahan hanya 3-5 hari sudah selasai persedian lagi.

Di Negeri Hatalai dalam pengolahan pohon mayang, penghasilan atau keuntungan yang bisa diperoleh oleh pemilik tersebut tergantung dari kuat dan lemahnya air sageru yang diteteskan oleh bunga atau tunas uang keluar dari pohon enau tersebut dan di olah. Satu pohon enau bisa menghasilkan tunas atau bunga dari pohon itu untuk diolah sebanyak lima sampai tujuh bunga. Satu bunga bisa menghasilkan sekitaran Rp. 7.500.00 ketika pohon enau itu mengeluarkan air sageru yang deras. Tetapi apabila air sageru tersebut keluar kurang deras, maka keuntungan dari satu bunga berkisar Rp. 5. 000.00. ketika satu pohon mayang sampai dengan selesai memproduksi Sopi dengan menghasilkan tujuh bunga untuk diolah, berarti keuntungan yang 
dapat diperoleh berkisaran Rp. 30. 000.00 itupun ketika air yang dihasilkan dari pohon enau dikategorikan bagus. Sedangkan ketika pohon mayang yang hanya menghasilkan sekitar lima bunga atau tunas, penghasilannya berkisar Rp. 20.000. 00. Sedangkan masa produktif satu pohon enau itu berkisar satu sampai dua Tahun lamanya.

Penghasilan dari mengolah Sopi ini adalah penghasilan yang tidak tetap jika dibandingkan dengan gaji seorang Aparatur Sipil Negara (ASN), Penghasilan Sopi tergantung dari kepandaian seorang tukang tifar Sopi dalam mengolahnya. Dalam memproduksi Sopi, resiko terbesarnya adalah kecelakan yang akan menimpa produsen Sopi apabila kurang hati-hati dalam memanjat maupun ketika turun dari pohon tersebut pada saat proses pengolahannya. Hal pertama dalam mengolah Sopi ini adalah kesehatan yang harus baik. Dalam dua hari air sageru diperoleh empat jerigen. Dari empat jerigen tersebut diolah dan disuling untuk menghasilkan Sopi dengan banyaknya Sopi tersebut diperoleh dalam ukuran satu jerigen saja melalui proses penyulingan. Dalam jangka waktu satu bulan, produsen Sopi dapat menghasilkan Sopi sebanyak lima belas jerigen. Lima belas jerigen keuntungannya per satu bulan Rp. 3.250.00,00 ketika satu jerigen dihargai dengan harga Rp 200.00.

Mengolah hasil alam untuk pemenuhan kebutuhan hidup tidaklah muda dan gampang. Khusus bagi produsen Sopi, demi memenuhi kebutuhan ekonomi keluarga, pengaturan ekonomi keluarga haruslah tepat. Berdasarkan pada hasil dan keuntungan dari Sopi yang tidak menentu, kadang cukup untuk memenuhi kebutuhan sehari-hari, kadang hasil sangat baik. Memproduksi Sopi dengan hasilnya sudah banyak membantu ekonomi keluarga. Penjualan Sopi selama ini terjadi di Negeri Hatalai dengan dua model. Model yang pertama, produsen Sopi menjual kepada pedagang lokal didalam Negeri Hatalai saja dengan jumlah yang sedikit (dua samapi tiga jerigen), seperti kios-kios kecil yang menjual Sopi. Model yang kedua, produsen Sopi biasanya menyetor hasil produksi Sopinya kepada penada yang datang dan membeli Sopi dari luar Negeri Hatalai dengan jumlah yang banyak (tiga sampai empat jerigen). Penada tersebut biasanya ketika membeli Sopi ke Hatalai, ia mendapatkan lima belas sampai dengan dua puluh jerigen Sopi yang di beli dari beberapa produsen-produsen Sopi yang ada. Dengan kata lain sudah terjadinya perjanjian kontrak antara produsen dan pembeli Sopi tersebut atau biasa di sebut dengan langganan.

Penyitaan dan razia Sopi sering dilakukan di Negeri Hatalai, tetapi dengan tindakan penyitaan yang biasa saja tanpa menumphakan Sopi. Jikalau ada penyitaan atau razia Sopi biasanya akan diberitahukan oleh pemerintah Negeri Hatalai dan disampaikan kepada tukang tifar mayang (produsen Sopi) untuk segera mengumpulkan masing-masing atau tiap-tiap produsen wajib mengumpulkan Sopi dengan ukuran satu botol bekas sprite sampai dengan Sopi yang dimuat dalam jerigen sebayak lima liter. Hal tersebut dilakukan agar supaya adanya bukti yang masuk ke pihak kepolisian bahwa telah tejadinya penyitaan Sopi di Negeri Hatalai. Tetapi selama ini untuk pihak keamanan dalam hal ini polsek setempat belum pernah turun langsung dan mengrazia sampai di rumah-rumah produsen.

Suatu saat jika terjadi pelarangan seutuhnya, dalam hal ini pemerintah Maluku melarang agar Sopi harus berhenti diproduksi dan berhenti dikonsumsi, maka akan mendatangkan kesusahan yang berkempanjangan bagi produsen Sopi. Selama ini ketergantungan terhadap Sopi dan hasil yang menguntungkan bagi ekonomi keluarga sudah berkepanjangan. Ketergantungan tersebut terjadi dikarenakan selama ini biaya hidup dan biaya menyekolahkan anak-anak didapatkan dari hasil penjualan Sopi. Kebijakan dari pemerintah setempat diharapkan untuk melihat kondisi Sopi ini terkait dengan kelegalannya. Melalui perkembangan dan berita yang diikuti terkait Sopi di Maluku, keputusan pemerintah untuk memusnahkan Sopi kelihatannya belum dikaji dengan benar, produsen Sopi mengharapkan adanya solusi yang diberikan juga dari pemerintah ketika ingin memusnahkan Sopi. Tetapi sampai dengan saat ini, solusi tersebut belum kami terima apabila terjadi pemberhentian memproduksi Sopi. "Selama ini kami hanya mengikuti aturan main dari pemerintah, kami juga kadang takut ditangkap ketika mengolah Sopi. Karena kalau tidak diolah air sageru tersebut keluarga kami tidak makan dan anak-anak kami tidak sekola"h. Ujar H.L. 
Sopi sudah menjadi bagian dari kehidupan. Sopi menghidupkan keluarga dengan hasil ekonominya. Produsen Sopi sangat setuju ketika Sopi itu dilebelkan dan legal di pasaran. Selain mengolah Sopi, penghasilan juga bisa didapatakan dari hasil hutan. Tetapi untuk hasil hutan penghasilannya jangka panjang, karena tanaman yang tumbuh dan menghasilkan buah di hutan Tersebut merupakan tanaman jangka panjang, seperti cengkih, pala, durian, buah-buah yang menghasilkan keuntungan untuk memenuhi kebutuhan keluarga hanya itu. Memang ada tanaman lain seperti kelapa, buah pala dan lain-lain tetapi masyarakat tidak mempunyai keahlian dalam mengolah hasil alam tersebut untuk penghasilan rumah tangga. Jika dibandingkan dengan Sopi, hasil kebun medatangkan keuntungan lebih lama. Penghasilan dari Sopi bisa terjadi setiap minggu bahkan hari, tetapi hasil hutan dengan tanaman jangka panjang dapa menghasilkan uang dalam jangka waktu 6 bulan satu kali panen. Maslah Sopi tergantung dari aturan main pemerintah. Harapannya Sopi tidak menjadi pertentangan di Maluku, apabila terjadi pertentangan akibat kebijakan dari pemerintah maka yang susah adalah rakyat kecil, khususnya petani Sopi.

\section{Sopi di Antara Cultural Capital dan Market Sphere}

Sopi sebagaimana dimaknai dan dipahami oleh masyarakat Maluku sebagai cultural capital orang Maluku ketika ada dalam penolakan serta pelarangan keberadaanya tentu saja akan menimbulkan perlawanan. Dalam pengertiannya cultural capital atau Modal budaya adalah semua literasi pengetahuan yang dapat dihasilkan melalui pendidikan formal dan warisan keluarga, kepemilikan benda budaya yang bernilai tinggi, serta pengetahuan dan keterampilan tertentu. Oleh karena itu, modal budaya merupakan representasi dari kecerdasan yang berkaitan dengan logika, etika, dan estetika. Atau gunakan bahasa lain untuk menyebutnya modal berdasarkan pengetahuan hukum. Modal budaya pada dasarnya berupa keyakinan (values) yang dianggap sebagai nilai yang benar, dan selalu berusaha untuk mewujudkannya. Modal budaya tidak akan otomatis terwujud dalam realitas yang bermanfaat bagi mereka yang mempercayainya dan / atau masyarakat secara keseluruhan. Perlu kemampuan dan dedikasi yang tinggi untuk memelihara, melestarikan, memperbarui dan menggunakannya (Sumarno; Haryanto; Bambang Saptono, 2013). Demikian yang terjadi dengan Sopi, sampai dengan saat ini telah menjadi warisan turun-temurun yang diwariskan dari para leluhur hingga saat ini sebagai sebuah pengetahuan yang berakar dan telah bernilai di mata masyarakat Maluku sebagai minuman yang mempersatukan dan yang dianalogikan Sopi sebagai air susu para leluhur. Sopi juga dikategorikan sebagai kedalam modal budaya oleh karena nilai kesakralan Sopi terwariskan secara turun temurun.

Sopi Maluku disebut juga warisan budaya, masyarakat terlibat dalam berbagai pekerjaan di bidang kehidupan mereka masing-masing. Konsep dan formula mereka adalah kearifan budaya, yang mereka digunakan untuk menciptakan dan berkreasi. Bentuk budaya harus dipahami sebagai sistem pengetahuan, gagasan, dan kepercayaan yang dimiliki oleh suatu masyarakat. Fungsi dan sistem pengetahuan ini memberikan panduan untuk sikap dan perilaku orang ketika mereka bersentuhan dengan lingkungan alam dan sosial mereka. Bagaimanapun, modal sosial dikendalikan oleh sistem pengetahuan, dan modal budaya yang dimiliki masyarakat merupakan kekuatan abstrak yang dapat memaksa dan membimbing warganya untuk bersentuhan dengan lingkungan alam dan sosial tempat mereka tinggal. Modal budaya yang dimiliki masyarakat merupakan kekuatan abstrak yang dapat memaksa dan membimbing pendukungnya untuk bertindak sesuai dengan sistem pengetahuan. Kebudayaan, sebagai suatu sistem, dimiliki oleh anggota masyarakat selama seluruh proses pembelajaran dari lahir sampai mati. Kapanpun kita menyadari atau tidak menyadarinya, budaya mengatur hidup kita, dan memang ada tekanan untuk mengikuti dan membentuk perilaku kita berdasarkan perilaku yang diciptakan oleh para pendahulu kita (Hamid, 2006).

Modal budaya terkandung dalam pengetahuan yang diperoleh secara sadar dan pasif melalui sosialisasi budaya dan tradisi. Berlawanan dengan properti, modal budaya semacam ini tidak dapat disebarkan, tetapi diperoleh dari waktu ke waktu, karena bergantung pada kebiasaan (karakter dan cara berpikir) seseorang, yang pada gilirannya lebih cenderung menerima pengaruh budaya yang serupa. Modal budaya bahasa adalah salah satu contoh modal 
budaya, di mana seseorang menguasai makna bahasa ketika berkomunikasi dan memperoleh citra diri dari budaya nasional. (Bourdieu, 1990). Objektivitas modal budaya mencakup properti seseorang (seperti karya seni, instrumen ilmiah, dll.), kemudian dapat disebarkan sebagai pendapatan ekonomi (penjualan), yang secara simbolis menyampaikan modal budaya tertentu melalui kepemilikan komoditas tersebut. Kepemilikan. Namun, dalam kasus kepemilikan karya seni (obyektifikasi modal budaya), pengguna atau pemilik karya seni memahami dengan benar makna historis dan fondasi dari modal budaya sebelumnya. Oleh karena itu, modal budaya semacam ini tidak dapat diwariskan melalui penjualan karya seni, kecuali jika penjual barangbarang tersebut menjelaskan pentingnya karya seni tersebut kepada pembeli. Modal budaya yang dilembagakan mencakup pengakuan kelembagaan formal atas modal budaya pribadi, biasanya dalam bentuk kualifikasi akademis atau profesional. Peran sosial terbesar dari modal budaya yang dilembagakan di pasar tenaga kerja. Ini adalah ekspresi "modal budaya" seseorang, yang digunakan untuk mengukur modal budaya kualitatif dan kuantitatif seseorang (kemudian dibandingkan dengan pengukuran "modal budaya" orang lain). Pengakuan lembaga formal mendorong pertukaran "modal budaya" dan "modal ekonomi" dengan memberikan solusi praktis yang memungkinkan "penjual" untuk menggambarkan modal budaya kepada "pembeli" (Bourdieu, 1986).

Ada lebih banyak penjelasan budaya, seperti buku "The Mirror of Man" oleh Siber dan Cruschune, The Relationship between Anthropology and Modern Life, yang dijelaskan pada tahun 1949. Pandangan ini berpendapat bahwa budaya adalah semacam "tradisi", tanpa henti, cukup mengikuti apa yang telah dilakukan. Eksistensi adalah realitas yang telah diciptakan dan dilembagakan. Jika kebudayaan dianggap sebagai warisan sosial, dan sebagiannya menjadi modal sosial yang nampak dalam bentuk tingkah laku dan objek produk, maka kegiatan penelitian di atasnya haruslah sebuah konsep yang dibentuk dalam kelompok etnis. Masih disekitar sudut pandang ini, dikatakan bahwa setiap budaya merupakan tatanan teknologi atau strategi adaptif yang ekosistemnya mendapat masukan dari luar. Strategi adaptif lahir dalam masyarakat melalui suatu lembaga yang berfungsi evaluasi, selektivitas dan dinamis dalam mengembangkan berbagai aspek budaya dan menghasilkan keluaran berupa perilaku antar pemangku kepentingan budaya. Semua ini merupakan hasil dari modal budaya, di dalam modal budaya terdapat kearifan lokal (local knowledge) dan kearifan lokal, dan menjadi sumber pengembangan budaya secara fleksibel melalui proses transformasi (Sieber and Kluckhohn, 1949).

Saat ini, Sopi sudah mengalami multi fungsi. Sejak dari awal Sopi tersebut ditemukan dan dilestarikan, Sopi telah menjadi bagian dari budaya dan adat-istiadat orang Maluku, kini Sopi juga telah berfungsi sebagai bagian dari pemenuhan kebutuhan ekonomi. Sopi telah berpengharu besar bagi perekonomian keluarga-keluarga di Kota Ambon terkhusus produsen Sopi. Sopi yang tadinya berada hanya sebatas warisan budaya, Sopi kini sudah masuk jauh ke ruang pasar akibat meningkatnya kebutuhan ekonomi. Di Indonesia, ketika batik diakui sebagai Situs Warisan Dunia oleh UNESCO, merupakan momentum penting untuk mengubah modal budaya menjadi modal ekonomi. Dari sini, batik tidak lagi identik dengan pakaian formal untuk melestarikan tradisi, tetapi lebih menunjukkan kreativitas, modernitas, bahasa, dan menjadi bagian dari kehidupan sehari-hari. Setelah batik, lahirlah gerakan budaya kopi yang dipicu oleh kualitas kopi Indonesia yang mendunia, namun kurang dikenal di Tanah Air. Kafe dari kategori merek global, kafe alternatif, kedai kopi, dan burung bintang (kedai kopi keliling) bermunculan. Di Indonesia terjadi pada daerah Nusa Tenggara Timur dan Manado yang mentranformasikan modal budaya ke modal ekonomi lewat Sopia dan Cap Tikus yang di legalisasi. Konsep "pasar budaya" berbeda dengan gagasan merevitalisasi pasar rakyat sebagai rumah ekonomi dan budaya bangsa Indonesia (Basri, 2012). Meskipun bentuk pasar yang lebih modern seperti supermarket telah dikembangkan, nilai budaya yang dihasilkan oleh hubungan sosial di pasar publik tidak tersedia di supermarket. Pasar rakyat merupakan tempat pertukaran nilai-nilai budaya melalui kegiatan ekonomi. Relasi sosial pasar rakyat dalam menentukan harga, kualitas, dan waktu perjanjian pasokan komoditas mendorong para pelaku untuk saling mengenal dan 
belajar dari kepribadian masing-masing untuk mendapatkan kesepakatan bersama yang wajar (Ekomadyo, 2018).

Konsep pasar telah berkembang dari lokasi fisik menjadi jaringan. Sebagai tempat, pasar mengacu pada tempat aktual, lokasi geografis di mana penawaran dan permintaan terpenuhi dan pertukaran terjadi, atau tempat di mana orang dan atau barang berkumpul untuk dipertukarkan. Sebagai segmen pasar, Anda dapat melihat sekelompok orang atau calon pelanggan. Sebagai salah satu jenis mekanisme pertukaran, pasar berhubungan dengan berbagai jenis sistem pertukaran, yang dapat dilihat melalui mekanisme pertukaran yang digunakan. Pasar sebagai suatu proses melibatkan transaksi pertukaran antara pembeli dan penjual dan tindakan agen lain yang memfasilitasi transaksi ini. Jaringan pasar dapat melihat kinerja terkoordinasi dari para pelaku pasar yang berinteraksi secara saling berhubungan(Sriadiana Sabianti, 2012). Menurut (Cooper and Lindblom, 2001) wirausahawan adalah elit dalam jaringan karena berperan dalam mendorong arus jaringan pasar, terutama kemampuannya untuk menciptakan lintasan baru antara produksi dan konsumsi.

Kegiatan mengolah Sopi yang terjadi di Kota Ambon sebagai modal usaha ekonomi keluarga dilatarbelakangi oleh kegiatan mengolah Sopi yang terjadi di Kota Ambon sebagai modal usaha ekonomi keluarga dilatarbelakangi oleh Pertanian Indonesia memiliki dua ciri yaitu, agribisnis besar biasanya dijalankan oleh perkebunan milik negara atau swasta dan agribisnis kecil yang biasa disebut agribisnis kecil. Kedua jenis usaha pertanian ini memiliki ciri khas masing-masing sehingga lebih mudah dibedakan (Soekartawi, 2007). Pertanian Rakyat secara umum merupakan subsistem yang menggunakan teknologi konvensional. Maluku yang termasuk Kota Ambon merupakan salah satu provinsi di Indonesia yang secara geografis merupakan kepulauan (pulau kecil), 92\% wilayahnya terdiri dari laut, dan kedua sisinya dikelola dalam bentuk pertanian rakyat. Tanah yang luas. Berbeda dengan pulau-pulau besar, kegiatan pertanian di pulau-pulau kecil harus dihargai dan diatur sedemikian rupa dengan menggunakan potensi sumber daya alam yang ada secara berkelanjutan (Notohadiprawiro, 2006). Sopi yang berasal dari hasil olahan pohon enau kini telah diolah dan dimanfaatkan oleh masyarakat Kota Ambon sebagai mata pencaharian dan penyokong ekonomi keluarga.

Ketika Sopi telah berada pada ruang pasar, kemudian usaha pemerintah untuk memusnahkan Sopi tersebut dari peredarannya dengan alasan Sopi merupakan pemicu kriminal. Keputusan pemerintah tersebut sangatlah bertentangan didalam masyarakat, dikarenakan kalau Sopi tersebut dimusnahkan, bagaimana dengan minuman beralkohol lain yang masih dipajang dan dijual pada pertokoan di Kota Ambon. Dilain sisi, pemerintah melarang memproduksi dan mengolah Sopi, tetapi solusi yang diharapkan dapat diterima dari pihak pemerintah juga tidak diberikan kepada produsen Sopi. Dan juga perbuatan penyitaan dan pemusnahan Sopi sangat tidak diterima dengan baik oleh masyarakat dikarenakan menurut masyarakat, sopi merupakan berkat dari Tuhan Sang Pencipta melalui pohon Enau, mereka harus mengolah dan menjual untuk kebutuhan finansial keluarga. Kebijakan adalah arah tindakan, yang tujuannya adalah untuk menentukan tujuan mengatasi masalah atau perubahan oleh peserta atau banyak peserta. Menurut Hoogerwerf, pada hakikatnya kebijakan adalah jawaban atas suatu masalah, upaya memecahkan, mengurangi, dan mencegah masalah dengan cara tertentu (yaitu melalui tindakan langsung)....hooger... Selain kesimpulan tentang definisi kebijakan yang didefinisikan, istilah "kebijakan" sekarang digunakan lebih sering dan lebih luas dalam kaitannya dengan tindakan pemerintah dan tindakan negara dalam arti umum (Hoogerwerf, 1983). Selain kesimpulan tentang definisi kebijakan yang didefinisikan, istilah "kebijakan" sekarang digunakan lebih sering dan lebih luas dalam kaitannya dengan tindakan pemerintah dan tindakan negara dalam arti umum (Muadi, MH and Sofwani, 2016).

Langkah pertama dalam mengajukan pertanyaan adalah merasakan bahwa ada masalah publik yang berbeda dengan masalah privat. Mendefinisikan masalah adalah tahap metaanalisis masalah sebagai masalah substantif. Ketika masalah substantif dapat didefinisikan, masalah formal yang lebih rinci dan spesifik dapat dirumuskan. Menganalisis proses perubahan dari masalah substantif ke masalah formal atau dari masalah formal ke masalah formal melalui deskripsi masalah Proses tersebut biasanya mencakup pengembangan model matematika 
formal dari masalah substantif. Setelah memahami secara seksama makna dari kebijakan tersebut di atas, maka sangat penting untuk mendeskripsikan makna kebijakan publik, karena pada dasarnya kebijakan publik sebenarnya berbeda dengan kebijakan privat (Komara, 2015). Pakar kebijakan publik telah mengungkapkan terlalu banyak definisi, tetapi banyak ilmuwan merasa sulit untuk benar-benar memahami kebijakan publik secara memuaskan. Hal ini disebabkan oleh sifat kebijakan publik yang luas, bukan spesifik dan dapat ditindaklanjuti. Luasnya implikasi kebijakan publik yang disampaikan (Muadi, MH and Sofwani, 2016). Muadi dan Sofwani mendefinisikan kebijakan publik sebagai hubungan antara departemen pemerintah tertentu dengan lingkungan. Definisi ini seolah memiliki makna yang luas, bahkan terkesan sulit untuk menemukan esensi dari kebijakan publik.

(Agustino, 2016) Berbagai pendapat yang memisahkan kebijakan publik dibagi menjadi dua kelompok. Pikiran pertama adalah bahwa kebijakan publik sama dengan tindakan yang diambil oleh pemerintah, sebagaimana dikatakan oleh Thomas K. Dye dalam (Agustino, 2016) bahwa "Kebijakan publik adalah apa yang dipilih pemerintah untuk dilakukan atau tidak" (terlepas dari apakah pemerintah memilih untuk melakukannya atau tidak). Meskipun makna kebijakan publik diberikan hanya dari satu perspektif (yaitu pemerintah), apa yang diungkapkan Thomas Day membuat perbedaan yang halus dalam makna kebijakan publik. Mungkin semua orang tahu bahwa kebijakan bukanlah keinginan pemerintah, tetapi masyarakat juga memiliki persyaratan (keinginan), karena pada prinsipnya kebijakan publik mencakup "apa yang harus dilakukan", "mengapa" dilakukan, dan konsekuensi "bagaimana" (Komara, 2015). Di sisi lain George dalam (Agustino, 2016) menunjukkan bahwa tidak ada definisi yang seragam dari kebijakan publik, yaitu, "pemerintah mengatakan dan melakukan atau tidak melakukan". Bahkan Easten dalam (Agustino, 2016) percaya bahwa distribusi nilai wajib / sah kepada seluruh anggota masyarakat. Berdasarkan definisi di atas, dapat disimpulkan bahwa kebijakan publik mencakup segala sesuatu. Diumumkan oleh pemerintah, diputuskan atau tidak diputuskan.

\section{Simpulan dan Saran}

Dari hasil penelitian, ditemukan bahwa Penghargaan terhadap Sopi sebagai minuman adat orang Maluku dan juga sebagai Cultural Capital ditandai dengan keeksistensian Sopi sampai dengan sekarang digunakan dan dipakai dalam ritual adat di Maluku. Berbanding terbalik dengan Sopi dalam ranah Market Sphere, Sopi masih belum mampu diregulasikan oleh pemerintah daerah. Pemerintah dinilai sewenang-wenang dan otoriter dalam menetukan keputusan dan kebijakan terkait Sopi di Maluku yang belum tiba pada kebijakan yang adil. Adapun kenyataan dilapangan bahwa masyarakat merasa resah dan bingung akibat kebijakan pemerintah yang merugikan rakyat khususnya bagi produsen Sopi, karena bagi mereka Sopi Sopi memegang peranan yang sangat penting dalam menunjang perekonomian keluarga. Temuan lapangan lain terkait dengan Sopi sebagai minuman adat lokal orang Maluku dijadikan alasan kriminalitas oleh pemerintah tanpa melibatkan bir, whisky, drum dan minuman keras jenis lainnya yang merupakan tudingan tanpa kajian dan penelusuran lapangan yang belum tuntas. Padahal faktorfaktor yang menimbulkan alasan kriminalitas bukan saja minuman keras Sopi, tetapi ada faktor lain yang mempengaruhi antara lain masalah ekonomi, politik, dan pendidikan. Ditempat lain selain di Maluku seperti NTT, Manado dan Bali pemerintah telah melegalkan dan meregulasikan Sopi. Legalisasi minuman beralkohol tradisional pada beberapa daerah diatas kiranya menjadi kontribusi bagi pemerintah dan Masyarakat Maluku agar berupaya mengatasi dan mengawal permasalahan Sopi dan peredaranya pada ruang publik. Penelitian ini belum sempurna, karena memiliki keterbatasan narasumber dari pihak pemerintah Daerah Maluku, dan terhalang pandemi Virus Corona-19. Sehingga untuk penelitian selanjutnya perlu untuk melakukan penelitian dan pembahasan yang lebih mendalam terkait permasalahan dan kontroversi pelegalan Sopi Maluku. 


\section{Daftar Rujukan}

Agustino, L. (2016) 'Dasar-Dasar Kebijakan Publik (Edisi Revisi)', Alfa Beta, p. 204. Available at: https://www.academia.edu/34144467/Dasar-dasar_Kebijakan_Publik_Edisi_Revisi_pdf.

Alex, A. (2019) "Sake", Minuman Khas Jepang Dari Fermentasi Beras, www.wortomatic.com. Available at: http://www.wortomatic.com/sake-minuman-khas-jepang-dari-fermentasiberas/ (Accessed: 12 August 2020).

Basri, M. C. et al (2012) Rumah Ekonomi Rumah Budaya. Cetakan Pe. Jakarta. Available at: https://books.google.co.id/books?hl=en\&lr=\&id=pFVJDwAAQBAJ\&oi=fnd\&pg=PP1\&dq=r umah+ekonomi+rumah+budaya:+membaca+kebijakan+perdagangan+Indonesia+pdf\&ots =gZotpjpQvJ\&sig=Zu-GGjRBLxlJtqI-qhOlSdU9Z7Q\&redir_esc=y\#v=onepage\&q\&f=false.

Bourdieu, P. (1986) 'Pierre Bourdieu 1986 - The forms of capital', Handbook of Theory and Research for the Sociology of Education. doi: 10.1002/9780470755679.ch15.

Bourdieu, P. (1990) Reproduction In Education, Society And Culture (second edition), London, England: SAGE Publications Ltd, 1990. xxvii+254 pp.

Cooper, R. N. and Lindblom, C. E. (2001) 'The Market System: What It Is, How It Works, and What to Make of It', Foreign Affairs. doi: 10.2307/20050273.

Creswell, J. W. (2015) Penelitian Kualitatif \& Desain Research Memilih di Antara Lima Pendekatan, alih bahasa, Ahmad Lintang Lazuardi.

Ekomadyo, A. S. (2018) 'Membangun Mutualisme Modal Budaya dan Modal Ekonomi', pp. 1-6.

Fransiska, A., Saka, D. and Nainggolan, E. E. (2019) 'Tinjauan Teori Compliance Tentang Tradisi Minum Moke Di Kabupaten Ende, Nusa Tenggara Timur', pp. 202-208.

Hamid, A. (2006) 'Potensi Modal Sosial Pada Budaya Lokal Dalam Pembangunan Daerah', Jurnal Jaffray, 4(1), p. 1. doi: 10.25278/jj71.v4i1.128.

Handoyo, P. (2019) Resmikan Minuman Beralkohol Lokal, Lawan Miras Oplosan!, www.rumahcemara.com. Available at: https://rumahcemara.or.id/meresmikan-minumanberalkohol-lokal-untuk-lawan-miras-oplosan/ (Accessed: 10 November 2020).

Hastanto, I. (2020) Polisi Jembrana Bali Pemeras Turis Jepang Dipenjara Empat Minggu, www.vice.com. Available at: https://www.vice.com/id/article/5dz755/dua-polisijembrana-bali-viral-peras-turis-jepang-rp1-juta-dihukum-penjara-28-hari (Accessed: 10 August 2020).

Hoogerwerf, A. (1983) 'Ilmu pemerintahan', p. 1983.

Indrayathi, P. A. (2004) 'Persepsi Produsen Arak di Desa Merita, Karangasem Mengenai Bahaya Keracunan Arak Oplosan yang Mengandung Metanol yang Dapat Mengancam Kesehatan dan Pariwisata di Bali', 2.

Kabartimur (2020) 2.400 Liter Sopi Dibuang ke Laut, www.kabartimurnews.com. Available at: https://www.kabartimurnews.com/2020/02/07/2-400-liter-Sopi-dibuang-ke-laut/.

Kadafi, M. (2019) Ribuan Miras Tradisional hingga Berbagi Merek di Bali Digilas Alat Berat, www.merdeka.com. Available at: https://www.merdeka.com/peristiwa/ribuan-mirastradisional-hingga-berbagi-merek-di-bali-digilas-alat-berat.html (Accessed: 10 November 2020).

Komara, E. (2015) 'Sistem Politik Indonesia Era Reformasi', Sistem Politik Indonesia Era Reformasi. doi: 10.15408/sd.v2i2.2814.Permalink/DOI.

Kompas.com (2019) Gubernur: Legalkan Miras Sopi di Maluku Timbulkan Perdebatan di Masyarakat, www.kompas.com. Available at: https://regional.kompas.com/read/2019/06/28/15181391/gubernur-legalkan-mirasSopi-di-Maluku-timbulkan-perdebatan-di-masyarakat (Accessed: 5 October 2019).

Lembaga Bantuan Hukum Masyarakat (2015) Kebijakan Minuman Beralkohol, www.lbhmasyarakat.org. Available at: http://lbhmasyarakat.org/wpcontent/uploads/2016/01/280116_Policy-Brief-Kebijakan-Minuman-Beralkohol_LBHMasyarakat.pdf (Accessed: 10 August 2020).

Lendo, J. (2014) 'Industri Kecil Kelompok Tani Cap-Tikus Masyarakat Desa Tokin Baru Kecamatan Motoling Timur Kabupaten Minahasa Selatan Oleh':, Acta Diurna, III(4).

M Agus Haryanto, I. N. L. dan B. S. (2020) Amankan Belasan Orang dan Ratusan Liter Ciu, 
www.jawapos.com.

Malaha, R. (2020) Polisi sita ratusan liter miras tradisional dari pegadang kios di Palu, www.antaranews.com.

Available

at:

https://sulteng.antaranews.com/berita/103102/polisi-sita-ratusan-liter-miras-

tradisional-dari-pegadang-kios-di-palu (Accessed: 9 November 2020).

Miles, M. B. and Huberman, A. M. (1994) 'Miles and Huberman 1994.pdf', Qualitative Data Analysis: An Expanded Sourcebook.

Muadi, S., MH, I. and Sofwani, A. (2016) 'Konsep Dan Kajian Teori Perumusan Kebijakan Publik', Jurnal Review Politik, 6(2), pp. 195-224. Available at: http://jurnalpolitik.uinsby.ac.id/index.php/jrp/article/view/90.

Notohadiprawiro, T. (2006) 'Tanah dan Lingkungan', Repro: Ilmu Tanah Universitas Gadjah Mada, pp. 1-22. doi: 10.1007/s00586-015-3838-9.

Nur Habibie (2020) Razia Tempat Produksi Miras di Jayawijaya, Polisi Amankan Ratusan Liter Ballo. Available at: https://www.merdeka.com/peristiwa/razia-tempat-pro.

Pelamonia, V. C. (2016) 'Pengetahuan dan perilaku remaja terkait Sopi serta dampaknya bagi kesehatan di skip, ambon - Maluku'.

Petrus, A. (2019) Sopia, Miras Khas NTT Resmi Diluncurkan, www.merdeka.com. Available at: https://www.merdeka.com/peristiwa/Sopia-miras-khas-ntt-resmi-diluncurkan.html (Accessed: 10 November 2019).

Rini, H. . (2012) 'Perilaku Kriminal Pada Pecandu Alkohol', pp. 1-19.

Saleky (2016) 'Ritual Tiris SOPI dalam perkawinan adat Di Desa Romkisar', Repository Universitas Kristen Satya Wacana, pp. 97-99.

Sarioa, B. (2011) 'Makna Minuman Keras " Sopi " Dalam Proses Rekonsiliasi Di Jemaat Gpm Wotay'.

Setiawan, H. K., Syafar, M. and Riskiyani, S. (2013) 'Aspek Persepsi Masyarakat Mengonsumsi Minuman Lokal "Sopi” Di Kabupaten Maluku Tengah Kecamatan Kota Masohi Kelurahan Namaelo Maluku Tengah', Universitas Hassanuddin, pp. 1-11. Available at: http://repository.unhas.ac.id/bitstream/handle/123456789/6017/Hadi Kohar Setiawan_K11109606.pdf?sequence=1.

Sieber, S. A. and Kluckhohn, C. (1949) 'Mirror for Man: The Relation of Anthropology to Modern Life', The American Catholic Sociological Review. doi: 10.2307/3707777.

Soekartawi (2007) Agribisnis: Teori Dan Aplikasinya, Seminar Nasional Aplikasi Tekonoli Informasi.

Sriadiana Sabianti, D. (2012) 'Nyamplung Di Jawa Tengah Dalam Perspektif Teori Jaringan - Aktor Dzuli Program Magister Studi Pembangunan Sekolah Arsitektur, Perencanaan dan Pengembangan Kebijakan INSTITUT TEKNOLOGI BANDUNG', Program Magister Studi Pembangunan Sekolah Arsitektur, Perencanaan dan Pengembangan Kebijakan.

Sumarno; Haryanto; Bambang Saptono (2013) 'Orientasi Modal Sosial Dan Modal Kultural Di Fakultas Ilmu Pendidikan U.N.Y.', Orientasi Modal Sosial Dan Modal Kultural Di Fakultas Ilmu Pendidikan U.N.Y., 6(2), pp. 68-77. doi: 10.21831/jpipfip.v6i2.4799.

Wattimena, L. E. (2013) 'Penggunaan Minuman Sopi Dan Persepsi Masyarakat Tentang Sopi Terhadap Kesehatan Di Desa Layeni Kecamatan Teon Nila Serua, Kabupaten Maluku Tengah', Skripsi.

Wildan, M. (2016) Penetapan Warisan Budaya Tak Benda Indonesia 2016, www.kebudayaan.kemdikbud.go.id. Available at: https://kebudayaan.kemdikbud.go.id/ditwdb/penetapan-warisan-budaya-tak-bendaIndonesia-2016/ (Accessed: 13 August 2020).

Yamani, Z. (2018) Buah Simalakama Pelarangan Minuman Beralkohol, www.dw.com. Available at: https://www.dw.com/id/buah-simalakama-pelarangan-minuman-beralkohol/a43405710-0 (Accessed: 11 August 2020). 